\title{
A proposal for health care management and leadership education within the UK undergraduate medical curriculum
}

This article was published in the following Dove Press journal:

Advances in Medical Education and Practice

12 February 2016

Number of times this article has been viewed

\author{
Cecilia Mafe \\ Effie Menyah \\ Munachi Nkere \\ Imperial College School of Medicine, \\ Imperial College London, London, UK
}

\begin{abstract}
Health care management and leadership education is an important gap in the undergraduate medical curriculum. Lack of training promotes poor decision making and may lead to inadequate health services, adversely affecting patients. We propose an integrated approach to health care management and leadership education at undergraduate level, to enable doctors to be effective leaders and manage resources appropriately and to ultimately improve patient care.
\end{abstract}

Keywords: health care, management, leadership, undergraduate, education, UK

\section{Introduction}

Health care management and leadership (HML) is a critical gap in undergraduate medical education. At present, it is the responsibility of medical schools to decide on how to teach students in this area, leading to vast differences in experience and understanding. Indeed, only a few medical schools offer Management as an intercalated Bachelor of Science, including Imperial College London and King's College London.

Annual growth in health care spending has drastically reduced since the financial crisis in 2008. ${ }^{1}$ As the prevalence of noncommunicable diseases increases in an aging population, there will be an inevitable strain on resources. Consequently, there is a renewed focus on resourcing primary care, as general practitioners (GPs) are responsible for managing long-term conditions and preventing complications, which form a large proportion of National Health Service (NHS) spending. ${ }^{2}$

The Francis Inquiry highlighted a lack of effective clinical leadership as a contributory factor to failed care at Mid Staffordshire NHS Foundation Trust, suggesting that strong leadership is required to build a patient-centered culture. ${ }^{3,4}$ The General Medical Council (GMC) stipulates that all doctors have a duty to appropriately manage resources, ${ }^{5}$ and since 2012 , the delivery of health services has been organized by GP-led clinical commissioning groups (CCGs). At present, half of all medical students are set to become GPs, ${ }^{6}$ with the remaining half in secondary care to meet the evolving health needs of the population. In light of this, we believe that HML should form an important part of undergraduate medical education and will be valuable to doctors working in both primary and secondary care.

\section{The importance of adequate training}

The GMC's Tomorrow's Doctors emphasizes the development of leadership skills, stating that doctors must "demonstrate ability to build team capacity and positive working relationships and undertake various team roles including leadership and the 
ability to accept leadership by others." "7 Both GPs and hospital doctors are in need of effective clinical leadership; thus, all undergraduates will benefit from HML education.

Furthermore, it is widely understood that senior doctors and professional nonclinical managers are responsible for managing health care. However, these concepts are important for medical students to understand so that future doctors will adapt to evolving health services effectively. There is no recognized pathway for doctors to pursue managerial and leadership positions, ${ }^{3}$ yet many GPs are faced with commissioning services during their careers. An article published by the Health Service Journal states, "Several CCG leaders said they were concerned about the lack of time they have to prepare to take on their additional responsibilities." ${ }^{8}$ Moreover, there are concerns about the lack of structure of health care management teaching within GP training, and this may adversely affect health services in the long term. ${ }^{9}$

\section{A way forward}

We propose a number of measures to ensure that future doctors are better equipped for management and leadership responsibilities. While it is unnecessary for all students to complete an intercalated Management Bachelor of Science, it is important to adopt an integrated approach to HML. This would include a short standardized module on managing health care organizations, broadly outlining concepts such as leadership, structure of the NHS, and resource allocation. Research has demonstrated positive attitudes to these concepts from students but cited lack of scheduled time as a barrier to engagement. ${ }^{10}$ Stringfellow et al also determined that " $65 \%$ of schools valued or highly valued the importance of teaching medical leadership and management topics, compared with $93.2 \%$ of students." 11

Moreover, Quince et al outlined the importance of developing broad perspectives at the undergraduate level and teaching topics relevant in the clinical context. ${ }^{12}$

Students should be given opportunities to explore management and leadership skills in the "real-world setting", such as shadowing GPs, attending relevant seminars, undertaking quality improvement projects, and participating in practical simulation exercises in which students take on various roles and manage fictitious services.

These modules need not be formally assessed, but students may document their reflections via an e-Portfolio, which has already become integral to doctors' appraisals. This precludes assessment overload as recommended in the Medical Leadership Competency Framework. ${ }^{13}$
In addition, curriculum change could be achieved by incorporation and further emphasis in future editions of the GMC's Tomorrow's Doctors. ${ }^{11}$

We believe this will provide students with a greater understanding of HML and enable future doctors to become effective clinical leaders.

\section{Conclusion}

To conclude, HML is an essential but often overlooked aspect of undergraduate medical training. We propose a combination of formal teaching and practical sessions, to provide an overview of health care management and enable future doctors to become effective clinical leaders and appropriately manage resources in primary and secondary care.

\section{Disclosure}

The authors report no conflicts of interest in this work.

\section{References}

1. Office for National Statistics. Total spend on healthcare in the UK in 2013 and a breakdown of public and private sector spending. Available from: http://www.ons.gov.uk/ons/rel/psa/expenditure-on-healthcare-inthe-uk/2013/info-healthcare-spending-in-the-uk-2013.html. Accessed September 19, 2015.

2. NHS England. The NHS Five Year Forward View. Available from: https://www.england.nhs.uk/wp-content/uploads/2014/10/5yfv-web. pdf. Accessed September 13, 2015.

3. Matthew Limb. What is deterring doctors from management roles? Available from: http://careers.bmj.com/careers/advice/What_is_deterring_doctors_from_management_roles\%3F. Accessed December 16, 2015.

4. Francis R. The Mid Staffordshire NHS Foundation Trust Public Inquiry. [Online]. Available from: http://webarchive nationalarchives.gov. uk/20150407084003/http://www.midstaffspublicinquiry.com/report. Accessed December 21, 2015.

5. General Medical Council. Leadership and management for all doctors working with doctors, working for patients. Available from: http:// www.gmc-uk.org/Leadership_and_management_for_all_doctors_ English_0315.pdf_48903400.pdf. Accessed September 15, 2015.

6. Department of Health. Delivering high quality, effective, compassionate care: developing the right people with the right skills and the right values. A mandate from the Government to Health Education England: April 2013 to March 2015. Available from: http://hee.nhs.uk/ wp-content/blogs.dir/321/files/2013/11/HEE-Mandate.pdf. Accessed September 13, 2015.

7. General Medical Council. Tomorrow's Doctors outcomes and standards for undergraduate medical education. Available from: http://www. gmc-uk.org/Tomorrow_s_Doctors_1214.pdf_48905759.pdf. Accessed December 16, 2015.

8. Welikala J. 63 CCGs take control of primary care budgets despite serious misgivings. Available from: http://m.hsj.co.uk/5084097.article. Accessed September 13, 2015.

9. Stirling A. McKinsey: NHS managers 'least clinically qualified' in developed world. Available from: http://www.pulsetoday.co.uk/ mckinsey-nhs-managers-least-clinically-qualified-in-developedworld/11044881.fullarticle. Accessed December 16, 2015.

10. Abbas MR, Quince TA, Wood DF, Benson JA. Attitudes of medical students to medical leadership and management: a systematic review to inform curriculum development. BMC Med Educ. 2011;11:93. 
11. Stringfellow TD, Rohrer RM, Loewenthal L, et al. Defining the structure of undergraduate medical leadership and management teaching and assessment in the UK. Med Teach. 2014;37(8);747-754.

12. Quince T, Abbas M, Murugesu S, et al. Leadership and management in the undergraduate medical curriculum: a qualitative study of students' attitudes and opinions at one UK medical school. BMJ Open. 2014;4(6);e005353-e005353.
13. NHS Institute for Innovation and Improvement and Academy of Medical Royal Colleges. Medical Leadership Competency Framework. Enhancing Engagement in Medical Leadership. Available from: http://www.leadershipacademy.nhs.uk/wp-content/ uploads/2012/11/NHSLeadership-Leadership-Framework-MedicalLeadership-Competency-Framework-3rd-ed.pdf. Accessed December $16,2015$.

\section{Publish your work in this journal}

Advances in Medical Education and Practice is an international, peerreviewed, open access journal that aims to present and publish research on Medical Education covering medical, dental, nursing and allied health care professional education. The journal covers undergraduate education, postgraduate training and continuing medical education including emerging trends and innovative models linking education, research, and health care services. The manuscript management system is completely online and includes a very quick and fair peer-review system. Visit http://www.dovepress.com/testimonials.php to read real quotes from published authors.

Submit your manuscript here: http://www.dovepress.com/advances-in-medical-education-and-practice-journal 